\title{
Adenocarcinoma arising in a cystic duplication of the small bowel: case report and review of literature
}

\author{
Gregor Blank ${ }^{1 *}$, Alfred Königsrainer ${ }^{1}$, Bence Sipos $^{2}$ and Ruth Ladurner ${ }^{1}$
}

\begin{abstract}
Enteric duplications are rare, but can occur anywhere along the digestive tract. Most of the patients become symptomatic in early childhood and only a few cases of adult patients have been reported in literature. Here we report a unique case of an adenocarcinoma arising in a coincidentally found cystic duplication of the small bowel.
\end{abstract}

Keywords: Enteric duplication, Duplication cyst, Malignant change, Small bowel cancer, Adenocarcinoma

\section{Background}

The term 'alimentary tract duplication' was characterized by W.E. Ladd to describe those congenital malformations that involve the mesenteric side of the associated alimentary tract and share a common blood supply with the native bowel [1]. Enteric duplications are unusual, but can occur anywhere along the digestive tract [2-7], most frequently found around the ileocoecal region [2-7]. Most patients become symptomatic within the first year of life [2-5]. Reports of enteric duplications in adulthood are extremely scarce in English language literature [8]. Although rare, malignant change can occur within the intestinal duplication [9]. In this report we present a case of an adenocarcinoma arising in a coincidentally found cystic duplication of the small bowel.

\section{Case presentation}

A 51-year-old man with no abdominal symptoms was admitted to our hospital with an external computed tomography (CT) scan showing a cystic mass in the mid-abdomen (Figure 1). The cystic mass was low-density and had enhanced margins. The size of the structure was measured at $4 \times 10 \mathrm{~cm}$ and it was located in the ileal mesenterium. The differential diagnosis

\footnotetext{
* Correspondence: gregor.blank@med.uni-tuebingen.de 'Department of General, Visceral and Transplant Surgery, University of

Tübingen, Hoppe-Seyler-Straße 3, D-72076 Tübingen, Germany

Full list of author information is available at the end of the article
}

contained a mesenteric cyst, a Meckel's diverticulum, and an enteric duplication.

Physical examination was unremarkable but laboratory tumor marker levels were slightly elevated: carcinoembryonic antigen (CEA) $13.2 \mu \mathrm{g} / \mathrm{l}$ (standard value $<5 \mu \mathrm{g} /$ l) and CA19-9 $55 \mathrm{kU} / \mathrm{l}$ (standard value $<37 \mathrm{kU} / \mathrm{l}$ ).

During explorative laparotomy a cystic mass was found in the mesenterium which looked similar to the small bowel but had no connection to the alimentary tract (Figure 2). The surface was smooth and without deposits. An en-bloc resection of the cystic mass could be performed without the necessity of a small bowel resection. At the end of the operation the specimen was opened (Figure 3). It contained an odorless, cloudy liquid. The luminal surface showed partly brownish deposits, the surface was irregular but smooth and the walls were uniformly $3 \mathrm{~mm}$ thick.

Histological examination revealed a duplication of the small bowel in the mesenterium with nearby physiological architecture. The inner lining mucosa showed indicated villi and crypts and numerous mucous cells. The epithelium showed partly dysplastic areas. At one point it contained a high-grade intraepithelial neoplasia with transition into a poorly differentiated invasive adenocarcinoma infiltrating the muscularis propria (Figure 4).

Immunohistochemistry revealed a high expression of CK20 and spot-like CK7. Analogue to the TNM-classification of the small bowel, the tumor was classified as pT2, pN0 (0/25), L0, V0, G2. 


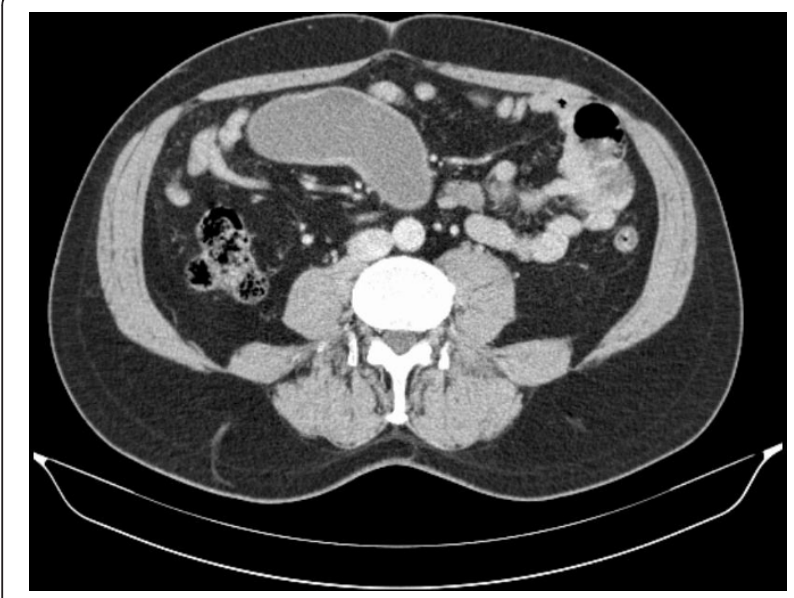

Figure 1 Computed tomography scan showing a low-density cystic mass $(4 \times 10 \mathrm{~cm})$ with an enhanced margin in the midabdomen.

Postoperative recovery was unremarkable and the patient was discharged six days after surgery. Regular oncologic follow-up in an outpatient setting for one year after surgery showed no hints of tumor recurrence with inconspicuous physical examination and normal tumor marker levels, ultrasound, and CT findings.

\section{Discussion}

Enteric duplications (EDs) are rare but can occur anywhere along the digestive tract from the oral cavity to the rectum $[2-7,10]$. The majority of ED occurs intraabdominally and over half of them are ileal duplications [4-7]. According to W.E. Ladd, those congenital

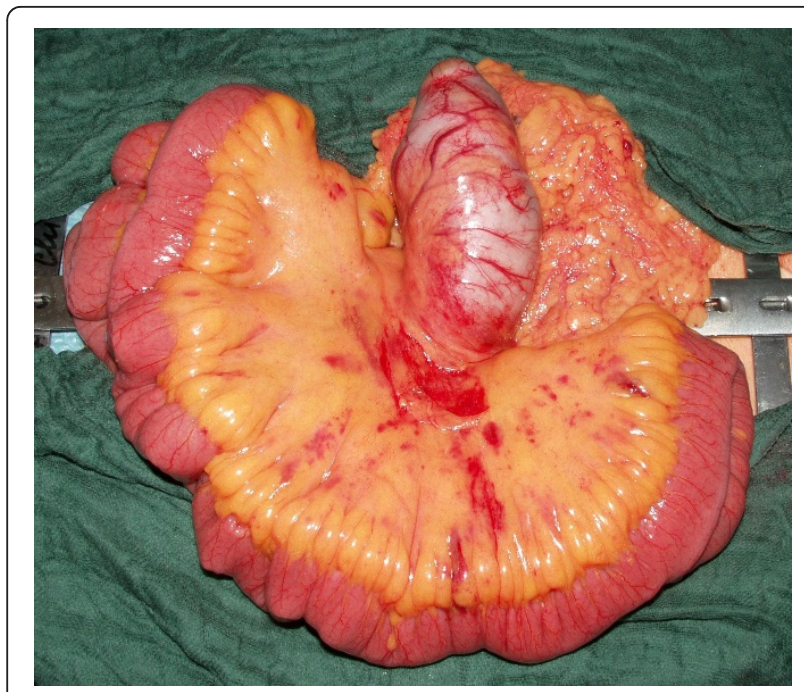

Figure 2 Intraoperative photograph showing the cystic mass in the mesenterium without a connection to the surrounding small bowel. The cystic mass bears great similarity to the small bowel.

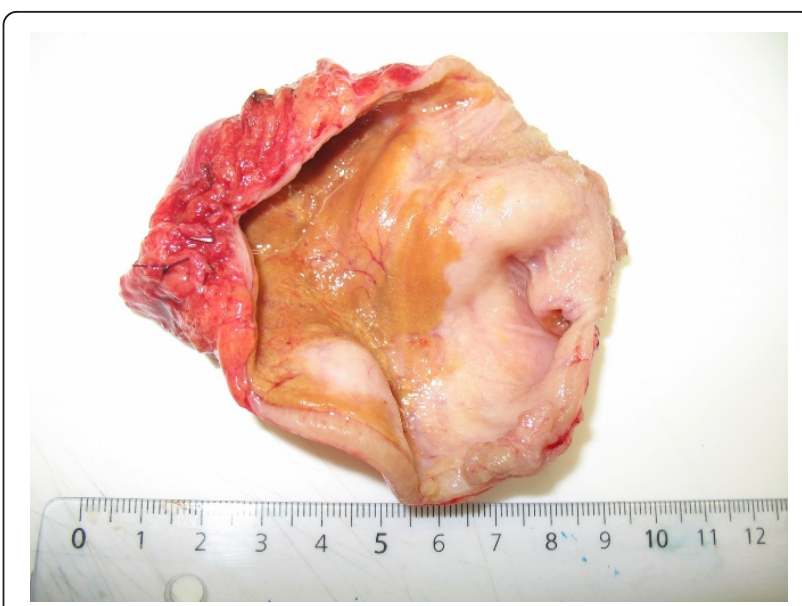

Figure 3 Macroscopic picture of the opened specimen. The luminal surface shows partly brownish deposits, the surface is irregular but smooth. The thickness of the walls is uniformly $3 \mathrm{~mm}$.

malformations involve the mesenteric side of the associated alimentary tract and share a common blood supply with the native bowel [1]. The etiology of ED still remains unknown. Several theories have been postulated such as an abnormal recanalization after the solid epithelial stage of embryonic bowel development [11]. Other theories consider persisting embryologic diverticula or 'aborted Gemini' [12]. The most accepted theory, however, is the 'intrauterine vascular accident theory' $[13,14]$, but no single theory can explain all the known duplications [7].

EDs usually become symptomatic within the first year of life [2-7]. Reports of ED in adulthood are extremely scarce in English language literature [8]. Most frequently, the patients present vague symptoms

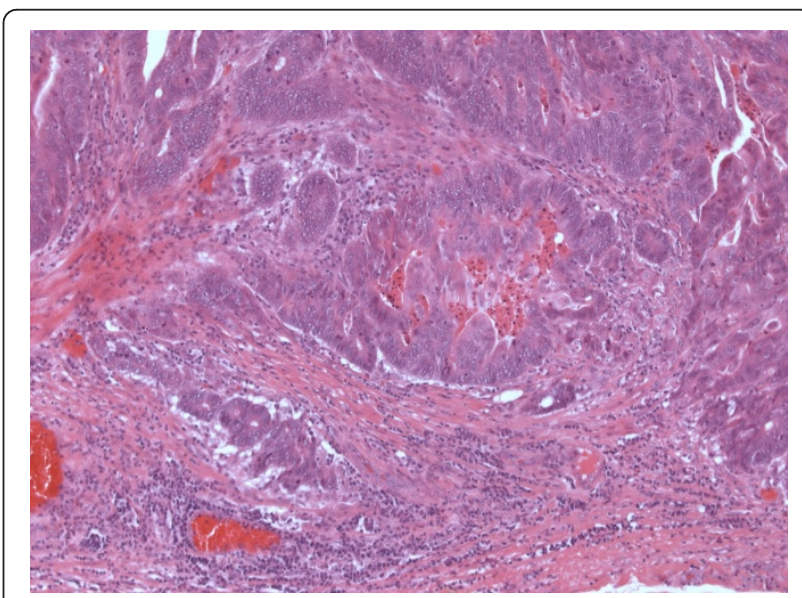

Figure 4 Microscopic picture (hematoxylin and eosin stain) showing a poorly differentiated invasive adenocarcinoma (intestinal type) infiltrating the lamina muscularis propria of the enteric duplication. 
mimicking other more common pathologies such as volvulus, appendicitis, intussusception, pelvic abscess, diverticulitis, achalasia, and Hirschsprung's disease [4,6,7,15-17].

EDs are most commonly diagnosed when complications like bowel obstruction, perforation, or bleeding occur. Prior to surgery it is difficult to diagnose EDs because of the non-specificity of symptoms and presentation. However, ultrasound, CT scan, and magnetic resonance imaging (MRI) have been useful. Ultrasound can depict the characteristic location adjacent to the bowel and the two-layered wall of EDs [15,18-20]. Bowel duplication cysts present with heterogeneous signal intensity on T1- and homogeneous signal intensity on T2-weighted images on MRI [21,22]. Latter modalities can even assist in prenatal diagnosis [22]. Where duplication is tubular, barium examination may be diagnostic if not contraindicated [7]. Technetium scanning can also be used to diagnose EDs [3]. The majority of EDs are isolated and cystic in structure. Reports of tubular duplications are less common. However, both could be associated with other malformations like intestinal malrotation and genitourinary or spinal malformations [23-25].

Heterotopic mucosa of gastric or pancreatic origin is a common finding in histological examination of ED [7]. In the current case the specimen had a similar physiological architecture to the small bowel with indicated villi, crypts, and a two-layered muscular wall. The epithelium contained many mucous cells. Gastric or pancreatic origin was not confirmed.

Carcinomas arising in duplication cysts are extremely rare complications and only few cases have been reported in literature including carcinoid tumors, squamous cell carcinomas, and common adenocarcinomas [26-50].

Malignant change in small bowel duplications is described most frequently [14,20,22,26-35], followed by colonic [36-43] and rectal [44-46] duplications. There are also reports about carcinomas arising in duplications of the duodenum $[47,48]$ and the stomach $[49,50]$. Due to the rare presentation with unspecific symptoms the tumors are commonly diagnosed at advanced tumor stage with metastatic disease [26-28,35]. If malignant change is found in small bowel duplications, the high rate of lymph node metastases should be considered [26]. The mode of metastasis is similar to that of primary small bowel cancer $[26,27]$. Curative resections could hardly be performed $[26,28]$. Thus, the prognosis is generally poor once malignant change has occurred. Fortunately the suspicion of ED was a coincidental finding in an abdominal CT scan in the present case. This led to a timely operative exploration and malignant change was diagnosed at an early stage. A curative en- bloc resection of the duplication including the tumor could be performed and all of the resected 25 lymph nodes were free of metastasis.

Histological examination depicted dysplastic areas in the epithelium with an area of a high-grade intraepithelial neoplasia and transition into a poorly differentiated invasive adenocarcinoma. This indicates a tendency to undergo malignant change, which was also reported by Orr and Edwards [9]. Moreover, all cases of malignant change in duplication cysts that have been reported have occurred in adults aged 26 to 88 years. This is in contrast to the presentation of benign cysts that are diagnosed in childhood [2,4-7].

\section{Conclusion}

The experience of this case and other reports about malignant transformation shows that whenever intestinal duplication is suspected, an immediate operative resection should be performed.

\section{Consent}

Written consent was obtained from the patient for the use and publication of this case report and the accompanying images. A copy of the written consent is available for review from the Editor-in-Chief of this journal.

\section{Author details}

${ }^{1}$ Department of General, Visceral and Transplant Surgery, University of Tübingen, Hoppe-Seyler-Straße 3, D-72076 Tübingen, Germany. ${ }^{2}$ Institute of Pathology, University of Tübingen, Liebermeisterstraße 8, D-72076 Tübingen, Germany.

\section{Authors' contributions}

GB collected the information, researched the literature, and wrote the article. AK helped with literature research and in preparing the manuscript. BS performed the histological examination and helped prepare the manuscript. $\mathrm{RL}$ helped in literature research and edited the final version of the manuscript. All authors read and approved the final version of the manuscript.

\section{Competing interests}

The authors declare that they have no competing interests.

Received: 5 December 2011 Accepted: 10 April 2012

Published: 10 April 2012

\section{References}

1. Ladd WE, Gross RE: Surgical treatment of duplications of the alimentary tract. Surg Gynecol Obstet 1940, 70:295-307.

2. Bower RJ, Sieber WK, Kiesewetter WB: Alimentary tract duplications in children. Ann Surg 1978, 188:669-674.

3. Hocking M, Young DG: Duplications of the alimentary tract. Br J Surg 1981, 68:92-96.

4. Schalamon J, Schleef J, Höllwarth ME: Experience with gastro-intestinal duplications in childhood. Langenbecks Arch Surg 2000, 385:402-405.

5. Karnak I, Ocal T, Senocak ME, Tanyel FC, Büyükpamukcu N: Alimentary duplications in children: report of 26 years' experience. Turk J Pediatr 2000, 42:118-125.

6. Kuo HC, Lee HC, Shin CH, Sheu JC, Chang PY, Wang NL: Clinical spectrum of alimentary tract duplication in children. Acta Paediatr Taiwan 2004, 45:85-88. 
7. Olajide ARL, Yisau A, Abdulraseed NA, Kashim IO, Olaniyi AJ, Morohunfade AO: Gastrointestinal duplications: experience in seven children and a review of the literature. Saudi J Gastroenterol 2010, 16:105-109.

8. Johnson JA, Poole GV: Ileal duplications in adults. Presentation and treatment. Arch Surg 1994, 129:659-661.

9. Orr MM, Edwards AJ: Neoplastic change in duplications of the alimentary tract. Br J Surg 1975, 62:269-274.

10. Chen MK, Gross E, Lobe TE: Perinatal management of enteric duplication cysts of the tongue. Am J Perinatol 1997, 14:161-163.

11. Bremer JL: Diverticula and duplications of the intestinal tract. Arch Pathol 1944, 38:132-140.

12. Letelier AM, Barría CM, Beltran MA, Moreno CCH: Duplicación intestinal: Diagnóstico y tratamiento de una condición inusual. Rev Chil Cir 2009, 61:171-175.

13. Favara BE, Franciosi RA, Akers DR: Enteric duplications. Thirty-seven cases: a vascular theory of pathogenesis. Am J Dis Child 1971, 122:501-506.

14. Beltrán MA, Barría C, Contreras MA, Wison CS, Cruces KS: Adenocarcinoma and intestinal duplication of the ileum. Report of one case. Rev Méd Chile 2009, 137:1341-1345.

15. Chou YH, Tiu CM, Pan HB, Yeh CJ, Wei CF, Chang TE: Ultrasonographic demonstration of duplication cyst of the ileum. Zhonghua Yi Xue Za Zhi (Taipei) 1990, 46:237-239.

16. Otter MI, Marks CG, Cook MG: An unusual presentation of intestinal duplication with a literature review. Dig Dis Sci 1996, 41:627-629.

17. Ameh EA, Jimoh AO, Rafindadi AH, Shehu SM: Sublingual gastric duplication cyst causing respiratory obstruction: case report. East Afr Med J 2000, 77:394-395.

18. Kangarloo H, Sample WF, Hansen G, Robinson JS, Sarti D: Ultrasonic evaluation of abdominal gastrointestinal tract duplication in children. Radiology 1979, 131:191-194.

19. Rice CA, Anderson TM, Sepahdari S: Computed tomography and ultrasonography of carcinoma in duplication cyst. J Comput Assist Tomogr 1986, 10:233-235.

20. Tew K, Soans BK, Millar EA: Adenocarcinoma in an ileal duplication cyst: ultrasound and computed tomography findings. Australas Radiol 2000, 44:228-231.

21. Berrocal T, Lamas M, Gutieèrez J, Torres I, Prieto C, del Hoyo ML: Congenital anomalies of the small intestine, colon and rectum. Radiographics 1999, 19:1219-1236.

22. Radich GA, Altinook D, Adsay NV, Soulen RL: Papilarry adenocarcinoma in a small-bowel duplication in a pregnant woman. AJR Am J Roentgenol 2006, 186:895-897.

23. Somuncu S, Cakmak M, Caglayan E, Unal B: Intestinal duplication cyst associated with intestinal malrotation anomaly: report of a case. Acto Chir Belg 2006, 106:611-612

24. Shah KR, Joshi A: Complete genitourinary and colonic duplication: a rare presentation in an adult patient. J Ultrasound Med 2006, 25:407-411.

25. Chaiyasate $K$, Bruch S: Colonic duplication associated with anterior spinal bar and left-sided inferior vena cava. Surgery 2007, 141:823-825.

26. Kusunoki N, Shimada Y, Fukumoto S, Iwatani Y, Ohshima T, Arahi E, Miyazaki N, Maeda S: Adenocarcinoma arising in a tubular duplication of the jejunum. J Gastroenterol 2003, 38:781-785

27. Kim TH, Kim JK, Jang EH, Lee JH, Kim YB: Papillary adenocarcinoma arising in a tubular duplication of the jejunum. Br J Radiol 2010, 83:e61-e64.

28. Devos B, Schreurs L, Duponselle E, Hendrix T, Van Dijck H, Van Vuchelen J: Adenocarcinoma optredend in een cystische duplicatie van het ileum. Acta Chir Belg 1987, 87:235-238.

29. De Tullio D, Rinaldi R, Pellegrini D, Stano R, Messina F, Cavazzini L, Azzena G, Occhionorelli S: Adenocarcinoma arising in an elderly patient's large ileal duplication. Int J Surg Pathol 2008, 19:681-684.

30. Babu MS, Raza M: Adenocarcinoma in an ileal duplication. J Assoc Physicians India 2008, 56:119-120.

31. Micolonghi T, Meissner GF: Gastric-type carinoma arising in duplication of the small intestine. Ann Surg 1958, 147:124-127.

32. Adair HM, Trowell JE: Squamous cell carcinoma arising in duplication of the small bowel. J Pathol 1981, 133:25-31.

33. Smith JHF, Hope PG: Carcinoid tumor arising in a cystic duplication of the small bowel. Arch Pathol Lab Med 1985, 109:95-96.

34. Ribaux C, Meyer P: Adenocarcinome dans une duplication intestinale grele. Ann Pathol 1995, 15:443-445.
35. Fletcher DJ, Goodfellow PB, Bardsley D: Metastatic adenocarcinoma arising from a small bowel duplication cyst. Eur J Surg Oncol 2002, 28:93-94.

36. Lee J, Jeon $\mathrm{YH}$, Lee S: Papillary adenocarcinoma arising in a duplication of the coecum. Abdom Imaging 2008, 33:601-603.

37. Heiberg ML, Marshall KG, Himal HS: Adenocarcinoma arising in a duplicated colon. Case report and review of literature. Br J Surg 1973, 60:981-982.

38. Arkema KK, Calendoff L: Adenocarcinoma in tubular duplication of the sigmoid colon. Gastrointest Radiol 1977, 2:137-139.

39. Hickey WF, Corson JM: Squamous cell carcinoma arising in a duplication of the colon: case report and literature review of squamous cell carcinoma of the colon and of malignancy complicating colonic duplication. Cancer 1981, 47:602-609.

40. Neal JW, Zuk RJ, Baithun SI: Squamous cell carcinoma in a duplicate large intestine. A case report. Virchows Arch A Pathol Anat Histopathol 1989, 415:383-385.

41. Delladetsima J, Papachristodoulou A, Zografos G: Carcinoma arising in duplicated colon. Am Surg 1992, 58:782-783.

42. Inoue $\mathrm{Y}$, Nakamura $\mathrm{H}$ : Adenocarcinoma arising in colonic duplication cysts with calcification: CT findings of two cases. Abdom Imaging 1998, 23:135-137.

43. Hattori $\mathrm{H}$ : Adenocarcinoma occurring just at the attached site of colonic duplication in an adult man. Dig Dis Sci 2005, 50:1754

44. Weitzel RA, Breed JR: Carcinoma arising in a rectal duplication (enterocystoma). Ann Surg 1963, 157:476-480.

45. Downing $\mathrm{R}$, Thompson $\mathrm{H}$, Alexander-Williams J: Adenocarcinoma arising in a duplication of the rectum. Br J Surg 1978, 65:572-574.

46. Gibson TC, Edwards JM, Shafig S: Carcinoma arising in a rectal duplication cyst. Br J Surg 1986, 73:377.

47. Falk GL, Young CJ, Parer J: Adenocarcinoma arising in a duodenal duplication cyst: a case report. Aust NZ J Surg 1991, 61:551-553.

48. Hata H, Hiraoka N, Ojima H, Shimada K, Kosuge T, Shimoda T: Carcinoid tumor arising in a duplication cyst of the duodenum. Pathol Int 2006 $56: 272-278$.

49. Coit DG, Mies C: Adenocarcinoma arising within a gastric duplication cyst. J Surg Oncol 1992, 50:274-277.

50. Kuraoka K, Nakayama H, Kagawa T, Ichikawa T, Yasui W: Adenocarcinoma arising from a gastric duplication cyst with invasion to the stomach: a case report with literature review. J Clin Pathol 2004, 57:428-431.

doi:10.1186/1477-7819-10-55

Cite this article as: Blank et al:: Adenocarcinoma arising in a cystic duplication of the small bowel: case report and review of literature. World Journal of Surgical Oncology 2012 10:55.

\section{Submit your next manuscript to BioMed Central and take full advantage of:}

- Convenient online submission

- Thorough peer review

- No space constraints or color figure charges

- Immediate publication on acceptance

- Inclusion in PubMed, CAS, Scopus and Google Scholar

- Research which is freely available for redistribution 